\title{
Utilization of Natural Zeolite Catalyst Impregnated Sn Metal in Glucose Isomerization With Temperature Variations
}

\author{
Dwi Putri W. Pamungkas ${ }^{1}$, Suci Amalia ${ }^{1}$, Ahmad Abtokhi $^{2}$, Susi Nurul Khalifah ${ }^{1}$ \\ ${ }^{1}$ Jurusan Kimia Fakultas Sains dan Teknologi UIN Maulana Malik Ibrahim Malang ${ }^{2}$ Nama Institusi \\ ${ }^{2}$ Jurusan Fisika Fakultas Sains dan Teknologi UIN Maulana Malik Ibrahim Malang ${ }^{2}$ Nama Institusi \\ Email: susikhalifah@gmail.com
}

\begin{abstract}
Studied the characteristics of natural zeolite catalysts activated and modifications and catalytic activity in the isomerization of glucose. Natural zeolite was activated by $\mathrm{NH}_{4} \mathrm{NO}_{3} 2 \mathrm{M}$ obtained catalyst HZA. While modification using 0,24 M Sn metal impregnated on HZA obtained catalyst Sn-HZA. At this stage, hydrothermal process carried out at temperature of $90{ }^{\circ} \mathrm{C}$ for 12 hours followed by calcination at temperature of $500{ }^{\circ} \mathrm{C}$ for 4 hours. The characterization includes the XRD analysis, SEM-EDAX analysis, acidity by ammonia method, and surface area by adsorption of methylene blue method. Glucose conversion was obtained through analysis of polarimeter at hour- $0,1,2,3$, and 4 with temperature variation of 110,120 , and $130{ }^{\circ} \mathrm{C}$. Solution which had the highest conversion resulted by polarimeter was analyzed by HPLC. XRD analysis showed that there were no changes in the structure of zeolite after activation and modification process. SEM-EDAX analysis showed that morphology of the zeolite surface is not damaged and $\mathrm{Sn}$ metal was successfully impregnated 6,94 \%. The activity of HZA and Sn-HZA was $1,4850 \mathrm{mmol} / \mathrm{g}$ and 2,3145 $\mathrm{mmol} / \mathrm{g}$. while the surface area of HZA and SnHZA was $11,4077 \mathrm{~m}^{2} / \mathrm{g}$ and $11,4738 \mathrm{~m}^{2} / \mathrm{g}$. Using the Sn-HZA catalyst with the reaction temperature of $120^{\circ} \mathrm{C}$ provides the highest conversion of glucose and fructose selectivity. It were 14,0733 \% w/v and 0,646\% w/v.
\end{abstract}

Keywords: Catalyst, glucose, isomerization, natural zeolite, Sn metal.

Abstrak

Telah dipelajari karakteristik katalis zeolit alam teraktivasi dan modifikasi serta aktivitas katalitiknya pada reaksi isomerisasi glukosa. Zeolit alam diaktivasi menggunakan $\mathrm{NH}_{4} \mathrm{NO}_{3} 2 \mathrm{M}$ menghasilkan katalis HZA. Sedangkan modifikasi menggunakan logam Sn 0,24 M yang diimpregnasikan pada HZA menghasilkan katalis Sn-HZA. Pada tahap tersebut dilakukan proses hidrotermal dengan suhu $90{ }^{\circ} \mathrm{C}$ selama 12 jam dilanjutkan kalsinasi dengan suhu $500{ }^{\circ} \mathrm{C}$ selama 4 jam. Karakterisasi meliputi analisis XRD, SEM-EDAX, analisis keasaman metode adsorpsi amoniak dan analisis luas permukaan metode adsorpsi methylene blue. HZA dan SnHZA diaplikasikan pada reaksi isomerisasi glukosa dengan metode batch. Konversi glukosa diperoleh melalui analisis polarimeter pada setiap jam ke-0, 1, 2, 3 dan 4 dengan variasi suhu 110, 120 dan $130{ }^{\circ} \mathrm{C}$. Larutan hasil analisis polarimeter yang menghasilkan konversi terbesar dianalisis dengan HPLC. Analisis XRD menunjukkan bahwa tidak terjadi perubahan struktur pada zeolit setelah proses aktivasi dan modifikasi. Analisis dengan SEMEDAX menunjukkan bahwa morfologi permukaan zeolit tidak rusak dan logam Sn yang berhasil diipregnasikan sebesar 6,94 \%. Keasaman HZA dan Sn-HZA yang diperoleh sebesar 1,4850 mmol/gr dan 2,3145 mmol/gr. Sedangkan luas permukaan H-ZA dan Sn-HZA sebesar $11,4077 \mathrm{~m}^{2} / \mathrm{gr}$ dan $11,4738 \mathrm{~m}^{2} / \mathrm{gr}$. Penggunaan katalis Sn-HZA dengan suhu reaksi $120^{\circ} \mathrm{C}$ dapat memberikan konversi glukosa dan selektivitas fruktosa terbesar yaitu $14,0737 \% \mathrm{~b} / \mathrm{v}$ dan $0,646 \% \mathrm{~b} / \mathrm{v}$.

Kata kunci: Katalis, glukosa, isomerisasi, zeolit Alam, logam Sn,

\section{PENDAHULUAN}

Industri makanan dan minuman banyak menggunakan pemanis sintetik Bahan pemanis ini lebih berbahaya bagi tubuh. Padahal makanan dan minuman yang banyak mengandung gula ini banyak digemari oleh anak-anak hingga orang dewasa.
Bahan pemanis yang dapat dipertimbangkan untuk mengganti bahan pemanis sintetik adalah fruktosa. Gula ini memiliki tingkat kemanisan lebih tinggi dan indeks glikemik lebih rendah daripada gula lainnya (Prabawati, 2006). Selain itu fruktosa adalah senyawa intermediet dalam pembentukan senyawa HMF 
(Hidroxymethylfurfural) yang merupakan prekusor penting dalam produksi biofuel (Barclay, dkk., 2012).

Fruktosa dapat dihasilkan melalui reaksi isomerisasi menggunakan katalis enzim. Katalis ini selektif namun memerlukan biaya pengolahan yang lebih tinggi akibat membutuhkan larutan penyangga untuk mempertahankan $\mathrm{pH}$, operasi suhu yang terbatas, membutuhkan tingkat kemurnian tinggi, dan penggantian enzim secara periodik karena adanya irreversible deactivation (Leshkov, dkk., 2010).

Katalis anorganik, seperti zeolit sintetik, dapat menggantikan katalis enzim dalam reaksi isomerisasi glukosa. Penelitian Moliner, dkk. (2010) menunjukkan bahwa penggunaan katalis Sn-Beta menghasilkan konversi glukosa sebesar $80 \%$ dan selektivitas fruktosa sebesar $30 \%$.

Aktivasi dan pengembanan logam pada zeolit alam akan meningkatkan aktivitas katalitiknya. Karena dengan proses tersebut luas permukaan dan keasaman katalis akan menigkat (Lestari,2010; Trisunaryanti, dkk., 2005). Berdasarkan penelitian Suharto, dkk (2007) zeolit alam yang telah diaktivasi dengan $\mathrm{NH}_{4} \mathrm{NO}_{3}$ memiliki luas permukaan lebih besar $\left(105,82 \mathrm{~m}^{2} / \mathrm{g}\right)$ dibandingkan zeolit alam yang tidak diaktivasi $\left(97,26 \mathrm{~m}^{2} / \mathrm{g}\right)$. Sedangkan Erlina (2012) melaporkan bahwa zeolit alam yang diimpregnasi logam Sn 0,24 M memiliki luas permukaan yang lebih besar daripada zeolit yang diimpregnasi logam Sn 0,48 M. Penelitian ini bertujuan untuk mengetahui karakterisasi zeolit sebelum dan sesudah aktivasi dan modifikasi, serta untuk mengetahui aktivitas katalitiknya pada reaksi isomerisasi glukosa.

\section{METODE PENELITIAN Bahan}

Zeolit alam Malang, akuades, $\mathrm{NH}_{4} \mathrm{NO}_{3}$ (Merck), methylene blue, amoniak p.a, D- glukosa monohidrat (Merck), L-fruktosa (Merck), $\mathrm{SnCl}_{2} \cdot 2 \mathrm{H}_{2} \mathrm{O}$ (Sigma Aldrich).

\section{Prosedur Penelitian \\ Preparasi Zeolit}

Zeolit alam dihaluskan dan diayak menggunakan ayakan 150 dan 200 mesh. Selanjutnya zeolit lolos ayakan 200 mesh ditimbang sebanyak 250 gram dan direndam dalam $500 \mathrm{ml}$ akuades sambil diaduk dengan pengaduk magnet selama sehari semalam pada suhu kamar. Kemudian disaring campuran dan endapan yang diperoleh dikeringkan dalam oven pada suhu $100{ }^{\circ} \mathrm{C}$ selama 24 jam. Zeolit hasil preparasi selanjutnya disebut ZA.

\section{Aktivasi Zeolit}

ZA ditimbang sebanyak 50 gram dan ditambahkan larutan $\mathrm{NH}_{4} \mathrm{NO}_{3} 2 \mathrm{M}$ sebanyak $100 \mathrm{ml}$. Kemudian campuran diaduk secara kontinyu selama 4 jam tanpa pemanasan. Campuran disaring dan dicuci dengan akuades sampai $\mathrm{pH}$ filtrat netral. Selanjutnya padatan yang diperoleh dipanaskan pada suhu $110{ }^{\circ} \mathrm{C}$ dalam oven selama 12 jam. Pada tahap ini dihasilkan zeolit aktivasi (H-ZA).

\section{Modifikasi Zeolit}

H-ZA ditimbang sebanyak $25 \mathrm{~g}$. Kemudian H-ZA dicampur dengan larutan $\mathrm{SnCl}_{2} .2 \mathrm{H}_{2} \mathrm{O}$ sebanyak $50 \mathrm{ml}$ dengan konsentrasi 0,24 M. Campuran diaduk selama 2 jam. Kemudian dilakukan proses hidrotermal dengan cara campuran dipanaskan pada suhu $90{ }^{\circ} \mathrm{C}$ dalam oven selama 12 jam dalam botol hidrotermal. Kemudian zeolit hasil hidrotermal disaring. Endapan yang dihasilkan kemudian dioven dengan suhu $100{ }^{\circ} \mathrm{C}$ selama 2 jam. Selanjutnya dilakukan kalsinasi pada suhu $500{ }^{\circ} \mathrm{C}$ selama 4 jam dalam tanur. Pada tahap ini dihasilkan zeolit modifikasi (SnHZA).

\section{Karakterisasi}

Karakterisasi dengan XRD dilakukan terhadap H-ZA, Sn-HZA dan $\mathrm{SnCl}_{2}$. Sampel disinari dengan sinar- $\mathrm{X} \mathrm{Cu}$ $\mathrm{K} \alpha=1,54 \AA$ ) pada sudut $2 \theta=5^{\circ}-60^{\circ}$ dengan 
kecepatan scan $0,02^{\circ}$ detik. Karakterisasi dengan SEM-EDAX dilakukan pada SnHZA dengan perbesaran 5000-20.000 kali. Analisis keasaman dan luas permukaan dilakukan pada ZA, H-ZA dan Sn-HZA. Analisis keasaman dilakukan dengan metode adsorpsi gas amoniak, sedangkan luas permukaan dengan metode adsorpsi methylene blue.

\section{Penentuan Aktivitas Katalitik H-ZA dan Sn-HZA}

\section{Isomerisasi Glukosa}

Isomerisasi glukosa dilakukan dengan metode batch menggunakan labu leher tiga yang dilengkapi dengan pengaduk, termometer dan refluks kondensor. Sebanyak $5 \mathrm{~g}$ glukosa dilarutkan dalam $50 \mathrm{~mL}$ aquades Selanjutnya ditambahkan H-ZA sebanyak 1 g. Kemudian larutan dipanaskan dengan variasi suhu 110,120 dan $130{ }^{\circ} \mathrm{C}$ dengan hotplate dengan kecepatan pengadukan 300 rpm. Diambil larutan sampel sebanyak 6 $\mathrm{mL}$ dan diletakkan dalam tabung reaksi pada setiap jam ke-0, 1, 2, 3 dan 4. Tabung segera diletakkan dalam lemari pendingin. Kemudian larutan disentrifus dan filtratnya dianalisis dengan polarimeter. Prosedur diulangi untuk katalis Sn-HZA.

Penentuan Konversi Glukosa dengan Polarimeter.

Dibuat kurva baku sudut putar bidang polarisasi spesifik glukosa $\left(\square_{\mathrm{sg}}\right)$ dan fruktosa $\left(\square_{\mathrm{sg}}\right)$ dengan larutan glukosa maupun fruktosa 2-12\%. Larutan sampel diambil sebanyak $1 \mathrm{~mL}$ dan diencerkan dengan akuades $25 \mathrm{~mL}$. Selanjutnya diukur sudut putar bidang polarisasinya dengan polarimeter dan dihitung konsentrasi glukosa sisa. Konversi glukosa dihitung menggunakan rumus :

Konversi $(\%)=\frac{\text { [glukosa awal]-[g]lukosa sisa] }}{\text { [g]lukosa awal] }} x 100 \%$

Analisis Hasil Isomerisasi dengan HPLC. Pengukuran dengan HPLC dilakukan pada larutan hasil pengukuran dengan polarimeter yang menghasilkan konversi terbesar. Larutan standar glukosa, fruktosa dan manosa dianalisis dengan kondisi:

Kolom

Fase Gerak

: Aminex HPX $87 \mathrm{C}$

Suhu Kolom

: Akuabides

Tekanan pompa: 3,2 $\mathrm{MPa}$

Flow Rate $\quad: 0,6 \mathrm{~mL} / \mathrm{menit}$

Elusi : Isokratik

Detektor :Refractive Index

Analisis larutan sampel dilakukan dengan kondisi yang sama dengan larutan standar. Analisis kualitatif dilakukan dengan membandingkan $\mathrm{R}_{\mathrm{t}}$ standar dengan sampel. Analisa kuantitatif dilakukan dengan menghitung konsentrasi senyawa glukosa, fruktosa dan manosa menggunakan rumus :

\%senyawa $=\quad \frac{\text { area senyalla }}{\text { area standar }} \times \%$ standar $\mathrm{x} \mathrm{fpx}$ -

\section{HASIL DAN PEMBAHASAN Difraksi Sinar-X (XRD)}

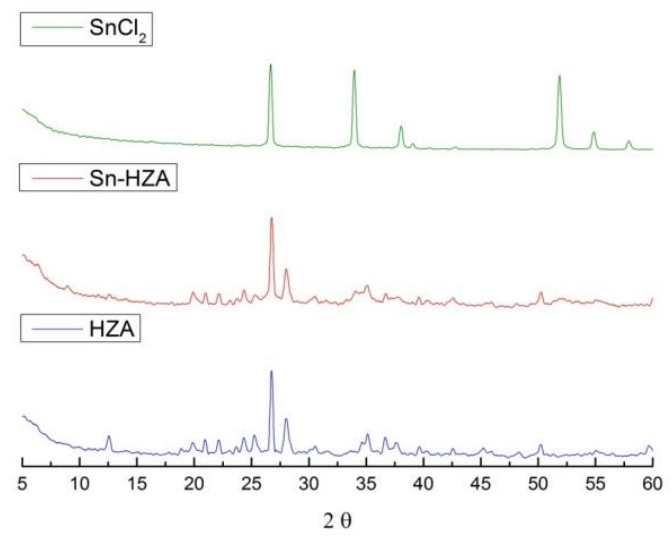

Gambar 1. Difraktogram H-ZA, Sn-HZA, $\mathrm{SnCl}_{2}$

Karakterisasi dengan XRD menghasilkan difraktogram H-ZA, Sn-HZA dan $\mathrm{SnCl}_{2}$ yang disajikan pada Gambar 1 . Zeolit alam Malang mengandung 55-85\% mineral jenis Mordenit (Laniwati,1999). Puncak khas mineral Mordenit berada pada $2 \theta=22,254^{\circ} ; 25,631^{\circ}$; dan $27,651^{\circ}$ (JCPDS No 700232) (Fatimah, 2010). Jika dibandingkan dengan difraktogram $\mathrm{H}-\mathrm{ZA}$ 
dan Sn-HZA maka terdapat kesesuaian puncak dengan puncak khas mineral Mordenit. Hal ini menunjukkan bahwa proses aktivasi dan modifikasi tidak merusak struktur awal zeolit. Namun masih terlihat adanya fase amorf pada difraktogram tersebut. Logam Sn berhasil diimpregnasikan pada Sn-HZA. Hal ini ditandai dengan adanya puncak khas $\mathrm{SnCl}_{2}$ dengan intensitas rendah pada difraktogram Sn-HZA yaitu pada $2 \theta=54,808^{\circ}$ dan penurunan intensitas pada puncak-puncak Sn-HZA.

\section{Analisis Morfologi dan Kandungan Sn- HZA dengan SEM-EDAX.}

Analisis dengan SEM-EDAX menunjukkan bahwa morfologi Sn-HZA memiliki bentuk kurang seragam. Hal ini menunjukkan bahwa masih ada fase amorf yang bercampur dalam strukutr Sn-HZA.

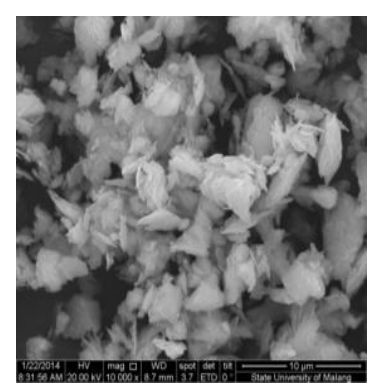

(a)

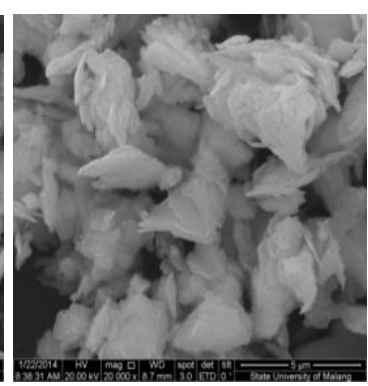

(b)
Gambar 2. Hasil SEM morfologi Sn-HZA perbesaran 10.000 kali (a), perbesaran 20.000 kali (b)

Hasil analisis kandungan unsurunsur pada zeolit modifikasi menunjukkan bahwa logam $\mathrm{Sn}$ yang berhasil diimpregnasikan sebesar 6,94\%. Hasil ini mendukung data XRD dimana logam Sn berhasil diimpregnasikan. Kandungan unsur terbesar adalah Si, Al dan O. Karena unsurunsur ini merupakan penyusun utama zeolit. Selain unsur-unsur tersebut juga masih terkandung logam seperti $\mathrm{Na}, \mathrm{Mg}$ dan $\mathrm{K}$ dan Fe.
Tabel 1. Kandungan unsur-unsur dalam SnHZA

\begin{tabular}{|c|c|}
\hline Unsur & \% berat \\
\hline $\mathrm{O}$ & 42.83 \\
\hline $\mathrm{Na}$ & 2.78 \\
\hline $\mathrm{Mg}$ & 2.19 \\
\hline $\mathrm{Al}$ & 10.63 \\
\hline $\mathrm{Si}$ & 23.18 \\
\hline $\mathrm{K}$ & 2.44 \\
\hline $\mathrm{Sn}$ & 6.94 \\
\hline $\mathrm{Fe}$ & 9.01 \\
\hline
\end{tabular}

\section{Analisis Keasaman Metode Adsorpsi Amoniak}

Penentuan keasaman dilakukan pada zeolit alam, H-ZA dan Sn-HZA dengan metode adsorpsi amoniak. Nilai keasaman dihitung berdasarkan selisih berat antara zeolit sebelum dan sesudah mengadsorp $\mathrm{NH}_{3}$. Jumlah $\mathrm{NH}_{3}$ yang teradsorp ekivalen dengan keasaman total zeolit. Menurut Trisunaryanti (2009) zeolit dapat digunakan sebagai katalis karena memiliki situs asam Brønsted dan Lewis. Sehingga dengan bertambahnya situs asam maka diharapkan aktivitas katalitiknya meningkat pula.

Menurut Gervasini, dkk. (2000) dalam Hidayah (2004) ikatan yang dibentuk $\mathrm{NH}_{3}$ dengan situs-situs asam meliputi beberapa cara. Pertama, adanya transfer proton dari gugus hidroksil pada permukaan pengemban ke adsorbat dan terjadi dengan situs asam Brønsted. Kedua, yaitu dengan membentuk ikatan koordinasi dengan kation-kation logam dan terjadi dengan situs asam Lewis melalui pendonoran pasangan elektron bebas dari adsorbat $\left(\mathrm{NH}_{3}\right)$. Cara ketiga merupakan cara yang paling lemah yaitu dengan pembentukan ikatan hidrogen.

Tabel 2. Keasaman total zeolit

\begin{tabular}{|l|c|}
\hline \multicolumn{1}{|c|}{ Sampel } & Keasaman Total $(\mathbf{m m o l} / \mathbf{g r})$ \\
\hline ZA & 1,4850 \\
\hline H-ZA & 2,3145 \\
\hline Sn-HZA & 2,6468 \\
\hline
\end{tabular}


Berdasarkan Tabel 2, H-ZA memiliki keasaman total lebih besar daripada zeolit alam. Meningkatnya keasaman dipengaruhi oleh ion $\mathrm{H}^{+}$pada kerangka zeolit dari proses pemanasan $\mathrm{NH}_{4}$-zeolit menjadi $\mathrm{H}$-zeolit dengan melepaskan gas $\mathrm{NH}_{3}$ (Nugrahaningtyas, dkk., 2009). Sn-HZA memiliki keasaman total yang paling besar dibandingkan zeolit alam dan zeolit teraktivasi. Hasil ini mendukung data XRD bahwa logam Sn telah terimpregnasi pada zeolit yang ditandai dengan peningkatan keasaman. Peningkatan ini terjadi karena logam Sn dapat bertindak sebagai asam lewis, sehingga dapat menambah situs asam pada zeolit tersebut (Corma dkk, 2003).

\section{Analisis Luas Permukaan Metode Adsorpsi Methylene Blue}

Selain keasaman, salah satu karakter lain yang dimiliki zeolit sehingga dapat digunakan sebagai katalis adalah luas permukaan. Luas permukaan merupakan parameter yang penting untuk katalis padat karena sangat menentukan aktivitas katalis (Istadi, 2011).

Luas permukaan zeolit ditentukan berdasarkan adsorpsinya terhadap methylene blue. Pengukuran luas permukaan dengan mengukur absorbansi methylene blue oleh zeolit menggunakan spektrofotometer UV-VIS dilakukan pada $\lambda=664 \mathrm{~nm}$ dan pada rentang waktu 50-70 menit. Proses adsorpsi terjadi ketika zeolit dicampurkan pada larutan methylene blue. Interaksi yang terjadi antara zeolit dan methylene blue disebabkan oleh beberapa kemungkinan. Pertama, adanya ion exchange antara ion $\mathrm{H}^{+}$pada HZA maupun Sn-HZA dengan kation methylene blue menyebabkan terjadinya interaksi elektrostatik antara muatan positif methylene blue dengan muatan negatif pada kerangka tetrahedral alumina. Muatan positif methylene blue terletak pada atom $\mathrm{N}$ atau atom S (Gambar 3) (Simoncic dan Armbruster, 2005). Kedua, interaksi antara gugus hidroksil pada permukaan zeolit dengan muatan positif methylene blue yaitu $\mathrm{OH}-\mathrm{S}$ atau ikatan hidrogen antara $\mathrm{OH}-\mathrm{N}$ (Canli, dkk., 2005). Ketiga, interaksi karena pembentukan ikatan hidrogen yaitu $\mathrm{CH}--\mathrm{O}$ pada kerangka mordenit (Simoncic dan Armbruster, 2005). Gugus $\mathrm{CH}$ berasal dari methylene blue, sedangkan atom $\mathrm{O}$ berasal dari kerangka pada permukaan zeolit.

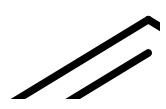

Gambar 3 Struktur methylene blue

Hasil analisis luas permukaan ZA, H-ZA dan Sn-HZA disajikan dalam Tabel 3. H-ZA memiliki luas permukaan lebih besar daripada zeolit alam. Hal ini dipengaruhi oleh proses aktivasi yang dapat mengurangi pengotor-pengotor yang terdapat pada zeolit sehingga dapat menambah luas permukaannya (Lestari, 2010). Sedangkan Sn-HZA memiliki luas permukaan paling besar dibandingkan zeolit alam dan H-ZA. Karena dengan pengembanan logam, maka luas permukaan katalis bertambah secara keseluruhan (Trisunaryanti, dkk., 2005). Dari hasil analisis luas permukaan yang diperoleh ini mendukung data XRD bahwa logam telah terimpregnasi pada zeolit. Dengan luas permukaan yang lebih besar maka diharapkan aktivitas katalitik zeolit akan lebih baik.

Tabel 3. Hasil Analisis Keasaman

\begin{tabular}{|l|c|}
\hline Sampel & Luas Permukaan $\left(\mathbf{m}^{2} / \mathbf{g r}\right)$ \\
\hline ZA & 11,4077 \\
\hline H-ZA & 11,4738 \\
\hline Sn-HZA & 11,6909 \\
\hline
\end{tabular}


Penentuan Aktivitas Katalitik H-ZA dan Sn-HZA

\section{Analisis Hasil Isomerisasi dengan Polarimeter}

Konversi glukosa ditentukan berdasarkan konsentrasi glukosa yang tersisa dari reaksi isomerisasi. Penentuan konsentrasi tersebut dilakukan pada larutan glukosa yang diperoleh dari reaksi isomerisasi pada masing-masing variasi suhu dan jenis katalis dalam setiap waktu menggunakan polarimeter. Hasil pengukuran menggunakan polarimeter adalah besarnya sudut putar bidang polarisasi glukosa. Dengan nilai sudut putar bidang polarisasi $\left(\alpha_{\mathrm{obs}}\right)$, nilai $\alpha_{\mathrm{sg}}$ dan nilai $\alpha_{\mathrm{sf}}$ dapat ditentukan konsentrasi glukosa sisa. Selanjutnya nilai tersebut digunakan untuk menghitung konversi glukosa masingmasing kondisi reaksi.

Analisis hasil isomerisasi menggunakan polarimeter dapat menunjukkan kondisi reaksi yang dapat memberikan konversi glukosa terbesar. Larutan dengan kondisi ini selanjutnya akan dianalisis dengan HPLC. Nilai konversi glukosa terbaik beserta kondisi reaksi disajikan pada Tabel 4.

Tabel 4. Hasil konversi glukosa menggunkan polarimeter

\begin{tabular}{|c|c|}
\hline Kondisi Reaksi & Hasil Konversi (\%) \\
\hline HZA $/ 130^{\circ} \mathrm{C} / 4 \mathrm{jam}$ & 20,59 \\
\hline $\mathrm{SnHZA} / 120^{\circ} \mathrm{C} / 4 \mathrm{jam}$ & 25,86 \\
\hline $\mathrm{SnHZA} / 130^{\circ} \mathrm{C} / 3 \mathrm{jam}$ & 25,38 \\
\hline $\mathrm{SnHZA} / 130^{\circ} \mathrm{C} / 4 \mathrm{jam}$ & 26,34 \\
\hline
\end{tabular}

Nilai konversi glukosa hasil analisis polarimeter dianalisis dengan menggunakan statistik. Hasil uji ANOVA menunjukkan bahwa ada pengaruh perlakuan yang signifikan terhadap konversi glukosa. Selanjutnya dengan uji BNT dihasilkan bahwa perlakuan dengan katalis Sn-HZA pada suhu $120{ }^{\circ} \mathrm{C}$ merupakan perlakuan yang paling berpengaruh terhadap konversi glukosa.

\section{Analisis Hasil Isomerisasi dengan HPLC}

Analisis HPLC dilakukan pada larutan hasil isomerisasi yang menghasilkan konversi glukosa terbesar berdasarkan analisis dengan polarimeter. Analisa kualitatif menunjukkan bahwa pada masing-masing larutan terkandung senyawa glukosa, fruktosa dan manosa. Hal ini dapat ditentukan dengan membandingkan nilai $\mathrm{Rt}$ masing-masing senyawa dengan Rt larutan standar senyawa tersebut. Berdasarkan nilai Rt, dapat diketahui urutan kepolaran masing-masing senyawa adalah : glukosa > manosa $>$ fruktosa.

Tabel 5. Nilai Rt masing-masing senyawa

\begin{tabular}{|l|l|l|}
\hline Senyawa & Rt (standar) & Rt (sampel) \\
\hline Glukosa & 9,267 & 9,283 \\
\hline Manosa & 10,833 & 10,783 \\
\hline Fruktosa & 12,733 & 12,717 \\
\hline
\end{tabular}

Analisa kuantitatif menunjukkan konsentrasi masing-masing senyawa dalam sampel. Berdasarkan hasil tersebut diperoleh bahwa semakin bertambahnya suhu maka konversi glukosa semakin menurun. Hal ini disebabkan glukosa sudah banyak yang terkonversi menjadi produk isomernya pada suhu $120{ }^{\circ} \mathrm{C}$. Sehingga kondisi terbaik yang dapat menghasilkan konversi terbesar adalah pada suhu $120{ }^{\circ} \mathrm{C}$ dengan katalis Sn-HZA. Nilai konversi yang dihasilkan melalui analisis HPLC berbeda dengan hasil analisis polarimeter. Hal ini disebabkan HPLC memiliki ketelitian yang berbeda dengan polarimeter.

Tabel 6. Hasil analisis kuantitatif HPLC

\begin{tabular}{|c|c|c|c|c|}
\hline \multirow{2}{*}{ Sampel } & \multicolumn{3}{|c|}{ konsentrasi } & \multirow{2}{*}{$\begin{array}{c}\text { Konversi } \\
\text { Glukosa } \\
(\%)\end{array}$} \\
\cline { 2 - 4 } & $\begin{array}{c}\text { Fruktosa } \\
(\%)\end{array}$ & $\begin{array}{c}\text { Manosa } \\
(\%)\end{array}$ & $\begin{array}{c}\text { Glukosa } \\
\text { sisa (\%) }\end{array}$ & 14,0059 \\
\hline $\begin{array}{c}\mathrm{HZA} / 130^{\circ} \mathrm{C} / 4 \\
\mathrm{jam}\end{array}$ & 0,5068 & 0,0959 & 9,2845 & 14,0737 \\
\hline $\begin{array}{c}\mathrm{SnHZA} / 120^{\circ} \\
\mathrm{C} / 4 \mathrm{jam}\end{array}$ & 0,6460 & 0,0803 & 9,7099 & 13,7134 \\
\hline $\begin{array}{c}\mathrm{SnHZA} / 130^{\circ} \\
\mathrm{C} / 3 \mathrm{jam}\end{array}$ & 0,3828 & 0,1024 & 9,4144 & 10,9161 \\
\hline $\begin{array}{c}\mathrm{SnHZA} / 130^{\circ} \\
\mathrm{C} / 4 \mathrm{jam}\end{array}$ & 0,3200 & 0,0123 & 9,0534 & 1 \\
\hline
\end{tabular}


Semakin bertambahnya suhu juga mengakibatkan penurunan selektivitas fruktosa. Jika dibandingkan antara jenis katalisnya, maka reaksi dengan katalis $\mathrm{H}$ ZA memberikan selektifitas fruktosa yang lebih besar daripada reaksi dengan katalis Sn-HZA pada suhu $130{ }^{\circ} \mathrm{C}$. Diduga pada suhu $130{ }^{\circ} \mathrm{C}$ dengan katalis Sn-HZA, reaksi lebih selektif pada pembentukan produk selain fruktosa. Dugaan ini didukung dengan konsentrasi manosa yang terbentuk, dimana pada suhu $130{ }^{\circ} \mathrm{C}$ dengan katalis Sn-HZA dihasilkan konsentrasi manosa yang lebih tinggi. Sehingga kondisi terbaik yang dapat menghasilkan konsentrasi fruktosa tertinggi adalah pada suhu $120{ }^{\circ} \mathrm{C}$ dengan katalis Sn-HZA.

Secara keseluruhan ditunjukkan bahwa semakin bertambahnya suhu, maka konversi glukosa dan selektivitas fruktosa menurun. Jika ditinjau dari jenis katalis didapatkan bahwa katalis Sn-HZA dapat menghasilkan konversi yang lebih besar daripada H-ZA. Selain itu Sn-HZA juga dapat meningkatkan selektifitas fruktosa. Hal ini sejalan dengan hasil keasaman total dan luas permukaan, dimana Sn-HZA memiliki keasaman dan luas permukaan yang lebih besar daripada H-ZA. Dengan keasaman yang tinggi akibat proses aktivasi dan pengembanan logam maka aktivitas katalis akan meningkat (Lestari, 2010). Selain itu luas permukaan yang besar akibat proses aktivasi dan pengembanan juga berpengaruh terhadap aktivitas katalis. Dengan semakin besarnya luas permukaan spesifik katalis maka pusat aktif katalis semakin banyak. Sehingga aktivitas katalis semakin meningkat pula (Tarigan, 2007).

Glukosa dan fruktosa merupakan pasangan isomer. Glukosa merupakan jenis monosakarida yang memiliki gugus aldehid. Sementara fruktosa merupakan jenis monosakarida yang memiliki gugus keton. Dengan demikian glukosa memiliki gugus karbonil $(-\mathrm{C}=\mathrm{O})$ pada $\mathrm{C}-1$, sedangkan fruktosa memiliki gugus karbonil $(-\mathrm{C}=\mathrm{O})$ pada $\mathrm{C}-2$.
Mekanisme reaksi isomerisasi glukosa menjadi fruktosa yang dikatalisis Sn-HZA diduga melalui jalur perpindahan atom $\mathrm{H}$ dari C-2 ke C-1. Hal ini didasarkan pada penelitian Leshkov, dkk., (2010) yang menunjukkan bahwa reaksi isomerisasi glukosa menjadi fruktosa terjadi dengan jalan pergeseran atom hidrogen intramolekuler oleh kehadiran Sn-Beta. Pusat logam dalam Sn-Beta berfungsi sebagai asam Lewis dalam media larutan air.

Reaksi isomerisasi menggunakan katalis Sn-HZA ini juga menghasilkan produk selain fruktosa yaitu manosa. Sebagaimana dalam penelitian Moliner, dkk (2010), reaksi isomerisasi glukosa yang dikatalisis oleh Sn-Beta dapat menghasilkan manosa sebesar $9 \%$ pada suhu $140{ }^{\circ} \mathrm{C}$.

Menurut Harris, dkk (1974), reaksi transfer hidrogen secara intramolekuler ditemukan pada reaksi isomerisasi aldosa menjadi ketosa dan ketosa menjadi aldosa dengan katalis asam. Sehingga pembentukan manosa dengan katalis SnHZA diduga berjalan dengan jalur transfer hidrogen. Reaksi isomerisasi ini bersifat endoterm $(\Delta \mathrm{H}=3 \mathrm{kj} / \mathrm{mol})$ dan reversibel (Moliner, dkk.,(2010). Adanya kenaikan suhu pada reaksi yang bersifat endoterm akan menggeser kesetimbangan reaksi ke arah produk. Dengan demikian ketika fruktosa telah terbentuk maka manosa dapat terbentuk pula pada suhu tertentu akibat pengaruh kesetimbangan termodinamik.

\section{KESIMPULAN}

Luas permukaan zeolit alam teraktivasi (H-ZA) dan zeolit alam modifikasi (Sn-HZA) berturut-turut adalah sebesar 11,4738 $\mathrm{m}^{2} / \mathrm{gr}$ dan 11,6909 $\mathrm{m}^{2} / \mathrm{gr}$. Sedangkan keasaman H-ZA dan Sn-HZA berturut-turut adalah sebesar 2,3145 $\mathrm{mmol} / \mathrm{gr}$ dan 2,6468 $\mathrm{mmol} / \mathrm{gr}$.

Suhu reaksi dan jenis katalis berpengaruh terhadap hasil isomerisasi glukosa. Suhu $120^{\circ} \mathrm{C}$ memberikan konversi 
dan selektivitas fruktosa terbesar. Semakin bertambahnya suhu maka konversi dan selektifitasnya berkurang. Penggunaan katalis Sn-HZA menghasilkan konversi glukosa dan selektifitas terbesar. Sehingga suhu reaksi $120{ }^{\circ} \mathrm{C}$ dan jenis katalis SnHZA merupakan perlakuan yang paling berpengaruh dimana konversi glukosa yang diperoleh sebesar $14,0737 \%$ b/v dan selektivitas fruktosa sebesar $0,646 \% \mathrm{~b} / \mathrm{v}$.

\section{DAFTAR PUSTAKA}

Barclay, T., Markovic, M.C., Cooper, P.D., and Petrovsky, N. 2012. The Chemistry And Sources Of Fructose And Their Effect On Its Utility And Health Implications. J. Excipients and Food Chem.Vol. 3, No. 2.

Canli, M., Abali, Y., and Bayca, S.U. 2013. Removal of Methylene Blue by Natural and $\mathrm{Ca}$ and $\mathrm{K}$-exchanged Zeolite Treated with Hydrogen Peroxide. Physicochem. Probl. Miner.Process. 49(2): 481-496.

Corma, A., Marcelo E., dan Susana V. 2002. Water-Resistant Solid Lewis Acid Catalysts: Meerwein Ponndorf-Verley and Oppenauer Reactions Catalyzed by Tin-Beta Zeolite. Journal of Catalysis. Vol. 215.

Fatimah, D. 2010. Pengolahan Mineral Tekto-Silikat Alam Untuk Substitusi lmpor Sediaan Bahan Baku Farmasi : Rekayasa Batuan Sebagai Basis Material AntiSeptik Melalui Penanaman Inhibitor dengan Metoda Kontinyu. Laporan Akhir Program Insentif Peneliti Dan Perekayasa LIPI.

Harris, W.D dan Milton S.F. 1974. Studies on the Mechanism of the Interconversion of D-Glucose, D Mannose, and D-Fructose in Acid Solution. Journal of the American Chemical Society. Vol. 97 No. 1.

Hidayah, C.N. 2004. Sintesis Katalis Co/Faah, Ni/Faah, Dan Cu/Faah: Hubungan Pola Pengembanan Dengan Urutan Nomor Atom Logam Katalis
Dalam Sistem Periodik Unsur. Skripsi. Surakarta: Fakultas Matematika dan Ilmu Pengetahuan Alam Universitas Sebelas Maret Surakarta.

Istadi. 2011. Teknologi Katalis untuk Konversi Energi. Yogyakarta: Graha Ilmu.

Laniwati, M. 1999. Isomerisasi 1-Buten

Menggunakan Zeolit Alam Asal

Malang Jawa Timur Sebagai Katalis.

Proc. ITB. Vol 31. No.2: 42.

Leshkov, Y. R., Moliner, M., Labinger, J.A., and Davis, M. E. 2010. Mechanism of Glucose Isomerization Using a Solid Lewis Acid Catalyst in Water. Angew. Chem. Int. Ed. Vol. 49: $8954-8957$.

Leshkov, Y. R., Moliner, M., Labinger, J.A., and Davis, M. E. 2010. Mechanism of Glucose Isomerization Using a Solid Lewis Acid Catalyst in Water. Angew. Chem. Int. Ed. Vol. 49: 8954 -8957.

Lestari, D.Y. 2010. Kajian Modifikasi dan Karakterisasi Zeolit Alam dari Berbagai Negara. Prosiding Seminar Nasioanal. Yogyakarta: UNY.

Lestari, D.Y. 2010. Kajian Modifikasi dan Karakterisasi Zeolit Alam dari Berbagai Negara. Prosiding Seminar Nasioanal. Yogyakarta: UNY.

Moliner, M. Leshkov. Y. dan Davis M.E. 2010. Tin-Containing Zeolites Are Highly Active Catalysts For The Isomerization of Glucose In Water. PNAS Early Edition: 1-5.

Nugrahaningtyas, D. 2009. Preparation And Characterization The Non Sulfided Metal Catalyst:Ni/USY and NiMo/USY. Indo. J. Che. Vol. 9. No. 2.

Prabawati, S. 2006. Gula Singkong dapat Diproduksi di Pedesaan. Warta Penelitian dan Pengembangan. Vol. 28, No. 3.

Simoncic, P and Armbruster, T. 2005.

Cationic Methylene Blue Incorporated into Zeolite Mordenite-Na: a Single 
Crystal X-ray Study. Microporous

and Mesoporous Materials No.81: 87

95.

Tarigan, S. 2007. Aktivitas Katalis

Cr/Zeolit Dalam Reaksi Konversi

Katalitik Fenol Dan Metil Isobutil

Keton. Jakarta: LIPI.

Trisunaryanti, W. 2009. Zeolit Alam

Indonesia Sebagai Adsorben dan

Katalis Dalam Mengatasi Masalah

Lingkungan dan Krisis Energi. Pidato

Pengukuhan Jabatan Guru Besar dalam

Ilmu Kimia. Yogyakarta: Universitas Gadjah Mada.

Trisunaryanti, W. Triwahyuni, E dan Sudiono S. 2005. Preparasi, Modifikasi dan Karakterisasi Katalis Ni-Mo/Zeolit Alam dan Mo-Ni/Zeolit Alam. Jurnal Teknoin, Vol. 10, No. 4: 269 -282. 